\title{
8. MICROFABRICS AND PATTERNS OF DYNAMIC RECRYSTALLIZATION IN GABBROIC ROCKS FROM THE MARK AREA, MID-ATLANTIC RIDGE ${ }^{1}$
}

\author{
John Fletcher, ${ }^{2}$ Georges Ceuleneer, ${ }^{3}$ and Mathilde Cannat ${ }^{4}$
}

\begin{abstract}
Gabbroic rocks sampled during Leg 153 record a continuous spectrum of microfabrics that range from magmatic to crystal plastic to cataclastic. Magmatic fabrics are defined to have less than $20 \%$ recrystallized plagioclase and they typically contain either aligned or randomly oriented euhedral plagioclase and ophitic to subophitic olivine and pyroxene. Crystal-plastic fabrics show a wide range of degrees of recrystallization. Plagioclase neoblasts are dominantly 100-200 $\mu \mathrm{m}$ in size, clinopyroxene neoblasts are dominantly $<100 \mu \mathrm{m}$, and olivine neoblasts show no dominant size. The crystal-plastic fabric contains a strong stretching lineation oriented parallel to the maximum-dip direction of a more weakly developed foliation. Kinematic indicators consistently show normal sense of shear across the foliation. On the basis of individual microstructures and patterns of dynamic recrystallization, clinopyroxene is significantly more competent in this ductile regime than plagioclase, and olivine has a relative competence intermediate between that of clinopyroxene and plagioclase.

The degree of plagioclase recrystallization increases with decreasing modal abundance of olivine and increasing abundance of orthopyroxene such that troctolitic gabbro is relatively less recrystallized than are gabbronorite and ferrogabbro. We interpret this strong partitioning of crystal-plastic deformation into more evolved gabbros to reflect, most likely, differences in hydrolytic weakening of the gabbroic rocks. Semibrittle and cataclastic fabrics also show normal-sense shear and are likely to have developed in response to the same tectonism that produced the higher grade fabrics.

Crosscutting relationships show that neoblast size progressively diminished and deformational style evolved from ductile to brittle. Microfabrics, compositional zoning of minerals, and synkinematic mineral assemblages demonstrate that deformation developed under progressively decreasing temperature and increasing pore-water pressure.
\end{abstract}

\section{INTRODUCTION}

Oceanic gabbros recovered during Leg 153 are exposed in the dipslope of a major east-dipping brittle-ductile normal fault, which makes up the western wall of the median valley of the Mid-Atlantic Ridge, immediately south of the Kane Fracture Zone (MARK area) (Karson, 1990). Gabbroic rocks record deformational fabrics that we interpret to have formed in conditions ranging from magmatic to lowgrade solid state. Variations in the character of deformational fabrics reflect changes in physical conditions of deformation (temperature, fluid pressure, and magnitude of deviatoric stress), changes in state of the rock (liquid to solid), and changes in the magnitude of accumulated strain.

This study uses a relational database to systematically record petrographic and microstructural data with the main purpose of comparing individual characteristics of various microfabrics in the suite of the gabbroic rocks. Through this approach, we document the microstructural evolution of the uplift and deformational history of gabbroic rocks. Additionally, the relative competence of mineral and rock phases is rigorously assessed in order to determine the nature of strain partitioning at the grain and crustal scales.

Along this oceanic ridge, the proximity of active magma systems with a crustal-scale shear zone segment suggests that rock fabrics are likely to be the product of both magmatic processes and mechanical extension. A principal result of this study is that patterns of dynamic

'Karson, J.A., Cannat, M., Miller, D.J., and Elthon, D. (Eds.), 1997. Proc. ODP, Sci. Results, 153: College Station, TX (Ocean Drilling Program).

${ }^{2}$ Departamento de Geologia, Centro de Investigación Científica y Educación Superior de Ensenada B.C., P.O. Box 434843, San Diego, CA 92143-4843, U.S.A. jfletche@ cicese.mx rance.

Observatoire Midi-Pyrénées, CNRS-UPR 234, 14 av. Ed. Belin, 31400 Toulouse,

${ }^{4}$ Laboratoire de Pétrologie, Université Pierre et Marie Curie, 4 place Jussieu 75252, Paris Cedex 05, France. recrystallization suggest that fractional crystallization may be an important process in controlling the strength of juvenile oceanic lithosphere.

\section{METHODS AND OBJECTIVES}

The database contains petrographic and microstructural information from approximately 160 samples of gabbroic rocks that were collected by numerous workers for applications that extend beyond this study. Therefore, the suite of samples shows a wide range of compositions and deformational fabrics. In samples with ductile fabrics, thin sections were typically cut perpendicular to foliations and parallel to stretching lineations. Additional thin sections from the other two principal planes of the fabric were also made from many of the samples. In samples containing brittle fabrics, thin sections were cut perpendicular to fracture surfaces and parallel to striae, when visible.

This work is a continuation of the classification scheme developed during shipboard characterization of thin sections (Shipboard Scientific Party, 1995a). As a result of time limitations, the shipboard scheme combined numerous textural criteria to classify thin sections into discrete microstructural groups. This approach worked well to define domainal variations in the downhole distribution of deformational fabrics, but individual characteristics of the fabrics were lost in the categories. For instance, predominant neoblast size varies from 100 to $500 \mu \mathrm{m}$ (almost the full range of neoblast sizes) in one microstructural group. Of course, this makes it impossible to determine internal characteristics of the size spectrum, such as degree of skewing or the presence and number of maxima, which are extremely important in defining the structural evolution of rocks in the fault zone.

The database consists of numeric fields for visual estimates of quantitative parameters, short text fields for specific qualitative data, and unformatted fields that accept observations as paragraph-style text or digital and object-oriented images. Visual estimates of modal 
mineralogy were made to test for the existence of host rock control on microstructural characteristics of rock fabrics (i.e., neoblast size and shape) and to determine if strain was partitioned between different rock types. Nature of alteration was entered in unformatted fields in the database. Secondary minerals were described in terms of nature of occurrence (e.g., whether or not they were found in veins or replacing specific primary minerals). Important reaction textures and equilibrium assemblages were also noted. The character of brittle microfabrics were also documented in unformatted fields. Some of the important characteristics were number of sets of veins and fractures, their orientations and spacing, and textural evidence for coeval crystal-plastic behavior.

Magmatic and high-grade solid-state fabrics were characterized using all the major types of data fields. Unformatted fields were used to describe fabric orientation, kinematic indicators, and domainal variations. Numeric and short text fields were used for the systematic description of fabric elements in each of the dominant minerals, plagioclase, clinopyroxene, and olivine. Some samples contain two or more spatial domains with significant differences in predominant neoblast size or rock type. Instead of averaging these compositional and textural variations, each domain was entered separately into the database. Although degree of recrystallization was never used as a criterion for defining domains, it commonly varied between domains defined by the other two criteria.

To make consistent measurements in every thin section, rigid distinctions were required between neoblasts, subgrains, and relict grains. Neoblasts were simply defined as anhedral grains with welldefined and predominantly convex boundaries. They generally show more than $5^{\circ}$ difference in extinction position from adjacent grains and are never penetrated by other grains. Neoblasts in most samples were likely to have formed from both grain- bulge nucleation and distinct strain-free nuclei (e.g., Hobbs et al., 1976). However, because of possible ambiguities, such genetic distinctions were not recorded in the database. Subgrains are bounded by straight, discontinuous walls, which are commonly diffuse and poorly defined. Subgrains also show smaller degrees of disorientation with neighboring grains than neoblasts. Anhedral relict grains are generally larger, penetrated by smaller neoblasts, have better defined twins, and can show more internal deformation. It is possible that relict grains, defined like this, could have been neoblasts from an earlier generation of recrystallization. However, such textures are not common, and it is unlikely that documenting such features would be very illuminating because of the subjectivity of their identification.
Perhaps one of the most important textural parameters is degree of recrystallization, which is simply the percentage of recrystallized neoblasts in the total grain population of any given mineral. Grainsize distributions of the neoblast population were visually approximated by measurements of the maximum, minimum, and predominant sizes. Predominant grain size was recorded in the database only when an obvious predominance existed in the grain-size distribution. Geometric characteristics of the shapes and boundaries of neoblast populations were entered in short text fields, which most commonly contained one of the following categories: sutured, lobate, irregular, or polygonal. These shapes crudely reflect differences in grainboundary mobility and in degree of primary recrystallization. Visual estimates of the relative strength of preferred lattice fabrics for each phase were recorded in short text fields as strong, moderate, or weak. The strength of plagioclase lattice fabrics was defined by preferred extinction positions in cross-polarized light, enhanced using a gypsum plate, and by preferred orientation of albite twins. Clinopyroxene lattice fabrics were defined by visual estimation of preferred cleavage orientations: strong fabrics were identified when cleavages are consistently oriented parallel and perpendicular to the foliation. Olivine lattice fabrics were defined by visual estimation of preferred extinction positions and by preferred orientations of subgrain walls of the grain population.

Commonly, both neoblasts and primary grains display internal deformation in the form of bent and kinked twins or cleavages, fanning and patchy extinction, and subgrain mosaics. An estimate of the relative intensity of the internal deformation (high, moderate, or low) and type of microstructures were recorded in the database. Primary grain characteristics, such as size and shape, were recorded only if the degree of recrystallization was less than $40 \%-50 \%$ and these features could be determined well. With higher degrees of recrystallization, only maximum relict grain size was recorded.

\section{MICROFABRICS}

Most of the fractional crystallization spectrum of gabbroic rocks is represented by the sample suite used in this study. Major rock types include troctolite, olivine gabbro, gabbro, gabbronorite, norite, and ferrogabbro norite. The flat histogram of degree of plagioclase recrystallization shows that the sample population is not skewed toward either strongly or weakly recrystallized samples (Fig. 1).
A

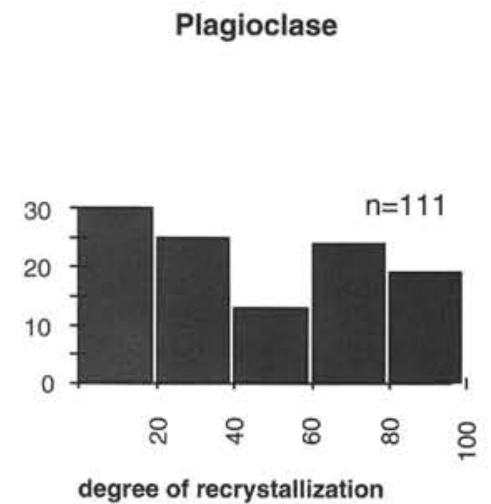

(\%)

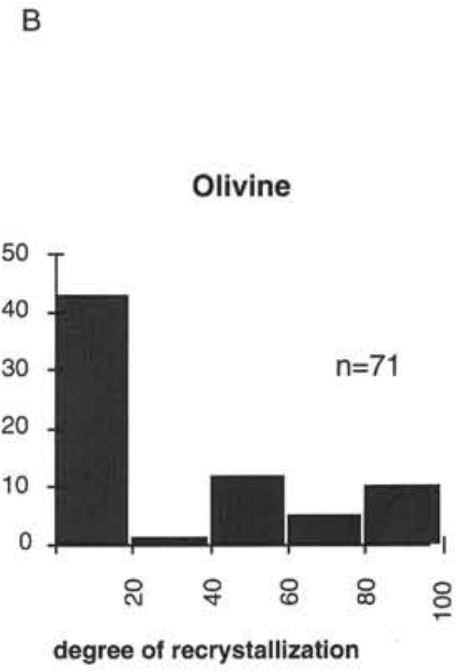

(\%)

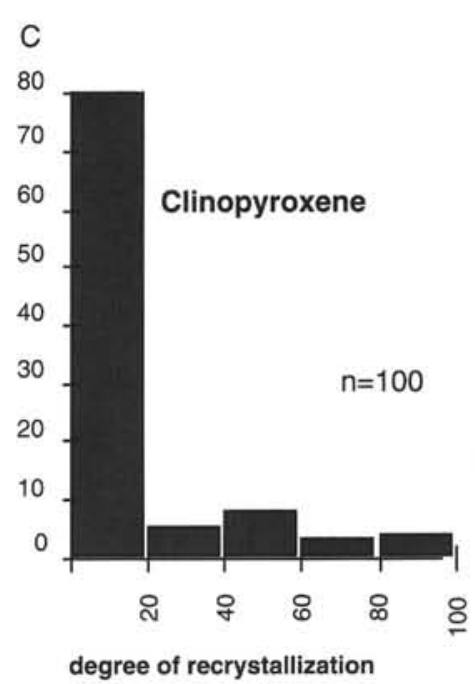

(\%)

Figure 1. Histograms showing degree of recrystallization of (A) plagioclase, (B) olivine, and (C) clinopyroxene. The plateau around 20 for all degrees of plagioclase recrystallization suggests that the sample population is not biased toward strongly or weakly recrystallized rocks. 


\section{Magmatic Fabrics}

Rocks with less than $20 \%$ recrystallization of plagioclase dominantly contain fabrics acquired during primary igneous crystallization. Most of the rocks in this category contain randomly oriented euhedral plagioclase with ophitic olivine and pyroxene. Less commonly, plagioclase laths display a crude alignment that could have formed either by settling and deposition in the magma chamber (e.g., Philpotts, 1990) or by flow of the magma-crystal mixture during crystallization (e.g., Patterson et al., 1989). Mesoscopically, the zones of aligned feldspar can be less than $5 \mathrm{~cm}$ thick and are bounded above and below by rocks with the same grain size and composition. These observations argue against a settling mechanism because the floor or substrate of deposition is not apparent. However, the thin zones could form in response to localized flow.

In some samples, pyroxene displays moderately to strongly preferred shape and lattice orientations, with almost no dynamic recrystallization of pyroxene and with low degrees of plagioclase recrystallization. For example, in Sample 153-923A-2R-1, 96-102 cm, pyroxene grains have aspect ratios of 2:1-6:1 and are strongly aligned. However, the degrees of recrystallization in plagioclase and pyroxene are only $30 \%$ and $5 \%$, respectively. If the evenly spaced pyroxene grains underwent a rigid-body rotation in the solid state, more than $40 \%$ of the surrounding plagioclase should have been recrystallized. Additionally, other samples with similar degrees of recrystallization show very little preferred dimensional orientation of pyroxene grains. Therefore, strong pyroxene shape fabrics in weakly recrystallized samples could have developed in a regime transitional between magmatic and solid-state conditions.

\section{Crystal-Plastic Fabrics}

Rocks containing a mesoscopic ductile fabric are common in the gabbro cores recovered during Leg 153. Microstructurally, these rocks show large variations in degree of recrystallization, neoblast size and shape, and amount of unrecovered internal lattice strain. However, the development of polygonal subgrain mosaics in zones of strong internal deformation in host grains, and the development of strong lattice preferred orientations in neoblast mosaics suggest that deformation was dominated by crystal-plastic flow (e.g., Rutter, 1986). This microstructural group is one of the largest in the sample suite and is arbitrarily chosen to include samples that contain more than $20 \%$ neoblastic plagioclase and no significant development of coeval fracturing.

\section{Degree of Dynamic Recrystallization in Different Minerals}

Throughout the suite of samples, variations in the degree of dynamic recrystallization are consistently associated with changes in grain shape. Within the same sample, recrystallized host grains always have a stronger preferred dimensional fabric than the unrecrystallized grains. This relationship occurs within monomineralic populations and among different mineral populations. For example, in Samples 153-923A-2R-2, 40-44 cm, and 153-923A-13R-1, 135-144 $\mathrm{cm}$, the degree of recrystallization of olivine $(60 \%, 70 \%$, respectively) is consistently higher than that of clinopyroxene $(30 \%, 20 \%$, respectively). Aspect ratios of olivine are consistently greater than $5: 1$, and many olivine neoblast trails extend beyond the dimensions of oversized thin sections. In contrast, aspect ratios of clinopyroxene grains in these samples never exceed 3:1. Such strain partitioning is also observed in partially recrystallized augen, which are commonly composed of strongly flattened recrystallized tails and subequant unrecrystallized cores. Therefore, in this suite of rocks, we interpret differences in the degree of dynamic recrystallization to reflect crude differences in strain magnitude. This interpretation is consistent with the results of a characterization of finite strain and microfabrics from a sheared metagabbro in north Brittany (Watts and Williams, 1983).
Two important subfields exist within the spectrum of degree of plagioclase recrystallization: $21 \%-60 \%$, and $61 \%-100 \%$ (Fig. 2). At $21 \%-60 \%$ recrystallization of plagioclase, rocks typically show relatively low $(0 \%-20 \%)$ degrees of recrystallization of olivine and pyroxene and thus deformation in these rocks is largely accommodated by plagioclase (Fig. 2). When plagioclase is more than $60 \%$ recrystallized, olivine and pyroxene also commonly show higher degrees of dynamic recrystallization. Interestingly, almost no samples display less than $50 \%$ recrystallization of olivine when plagioclase is more than $80 \%$ recrystallized. In contrast, numerous samples show less than $50 \%$ pyroxene recrystallization when plagioclase is more than $80 \%$ recrystallized (Fig. 2). Sample $153-923 \mathrm{~A}-2 \mathrm{R}-1,30-36 \mathrm{~cm}$, shows nearly complete recrystallization of plagioclase and almost no recrystallization of clinopyroxene (Figs. 3A, B). These results suggest that, in terms of relative competence of the three phases, clinopyroxene was the most competent, olivine was intermediate, and plagioclase was the least competent. Agar (1994) found a similar difference in degree recrystallization of pyroxene and plagioclase, but did not establish how the degrees of recrystallization of these minerals compare with that of olivine.

Small-scale microstructural evidence for the relative competence of clinopyroxene and olivine is abundant and consistently shows that clinopyroxene is more resistant to dynamic recrystallization. In samples with high degrees of plagioclase recrystallization, clinopyroxene is commonly porphyroclastic, whereas olivine typically occurs as much thinner neoblastic trails or in strain-shadow positions around clinopyroxene (Fig. 4A). The difference in competence is especially striking when the two minerals are proximate. In Figure 4B, an unrecrystallized clinopyroxene porphyroclast shares a grain boundary with a highly recrystallized olivine host grain. Oxide pressure shadows around the clinopyroxene grain show that it is not outside of the zone of deformation that affected the recrystallized olivine grain.

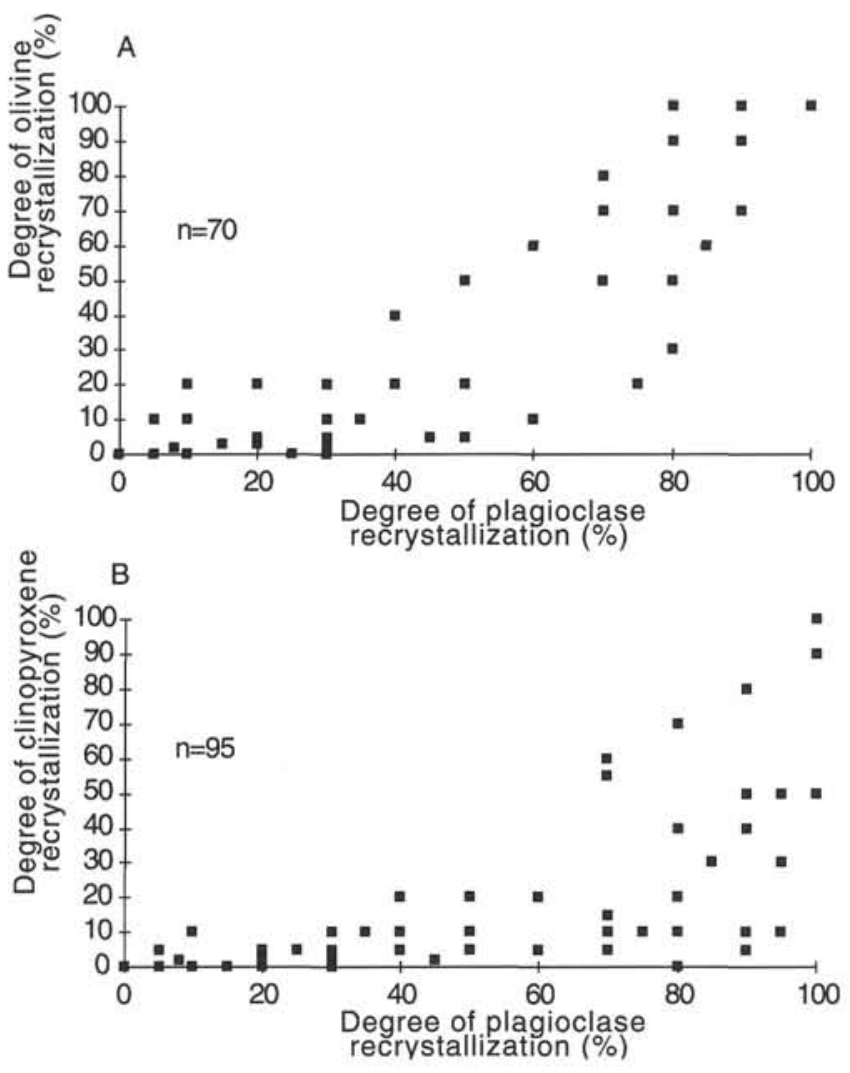

Figure 2. Relative degrees of dynamic recrystallization. Degree of recrystallization of plagioclase is plotted vs. that of (A) olivine and (B) clinopyroxene. 

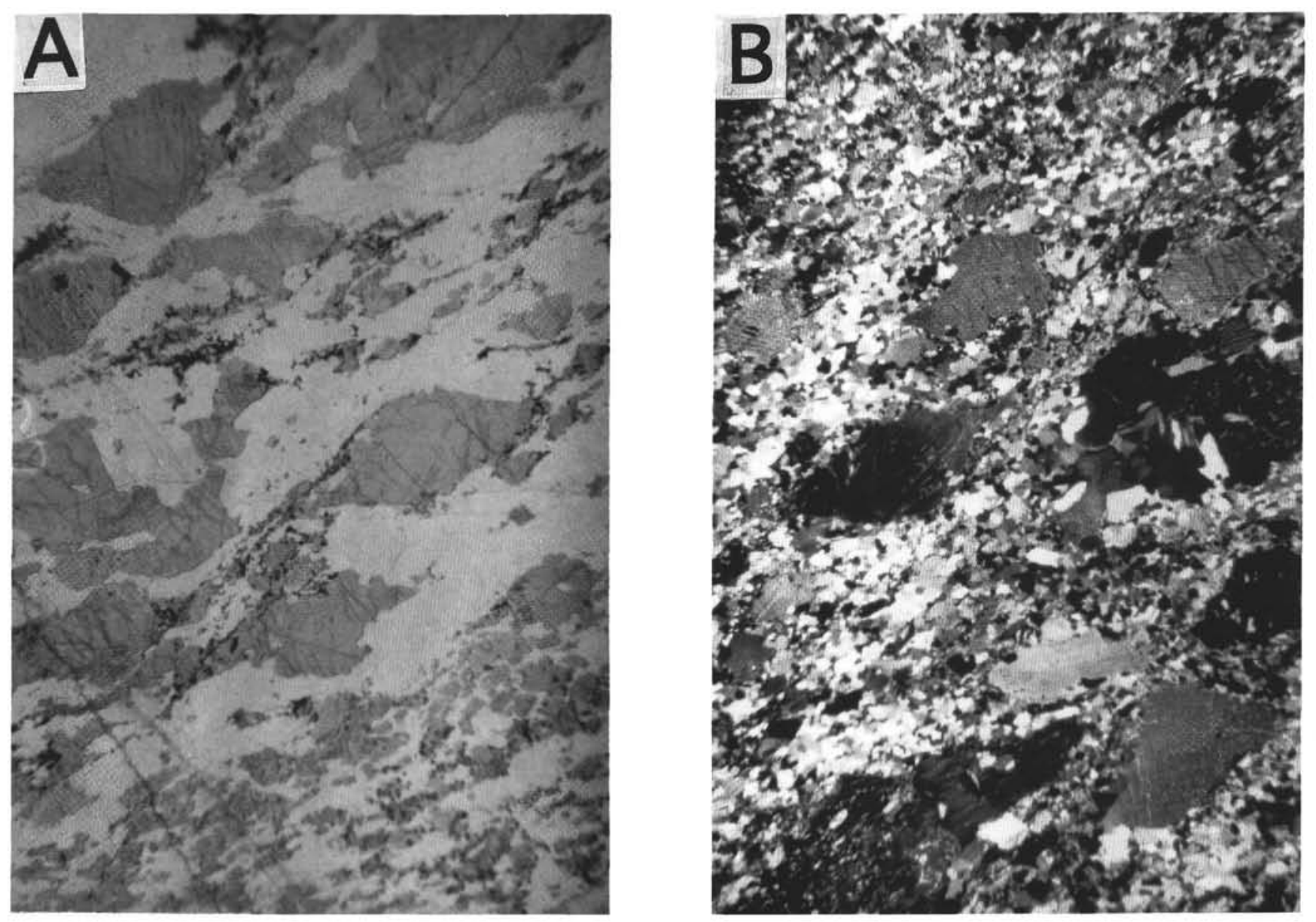

Figure 3. Porphyroclastic clinopyroxene in matrix of strongly recrystallized plagioclase (Sample 153-923A-2R-1, 30-36 cm). A. Plane-polarized light. B. Cross-polarized light. Clinopyroxene porphyroclasts show a weak sinistral asymmetry. Dark thin tails on some porphyroclasts are composed of olivine and iron oxide. Field length is $2 \mathrm{~cm}$. Uphole direction is parallel to the long axes of both photographs.

Therefore, the difference in degree of recrystallization probably reflects differences in competency of the two minerals.

In addition to the onset of olivine and pyroxene recrystallization, several other important transitions in microstructural style occur in the interval from $21 \%$ to $100 \%$ recrystallization of plagioclase. At low degrees of recrystallization, plagioclase neoblast mosaics are commonly irregularly shaped and have a patchy distribution throughout the thin section. In rocks with coarser plagioclase neoblasts (300$500 \mu \mathrm{m}$ ), incipient recrystallization primarily occurs along margins of primary grains, resulting in core-mantle textures as degree of recrystallization increases. In contrast, incipient recrystallization of rocks with the finest plagioclase neoblasts $(30-150 \mu \mathrm{m})$ commonly also occurs through the interior of plagioclase grains, forming thin trails of neoblasts or neoblast necklaces.

At degrees of recrystallization of about $30 \%-40 \%$, plagioclase neoblast mosaics are organized into anastomosing zones. Shear-zone wall geometry is variable, but straight sharp walls are more common in rocks with smaller neoblasts $(100-300 \mu \mathrm{m})$, whereas boundaries are more irregular and diffuse with larger neoblast size $(300-500$ $\mu \mathrm{m})$. At about $50 \%$ dynamic recrystallization, primary-grain contacts are largely destroyed and cores of relict grains float in the neoblast mosaic.

\section{Degree of Dynamic Recrystallization in Different Rocks}

Degree of recrystallization of plagioclase is strongly correlated with modal mineralogy of the host rock (Fig. 5). Degree of recrystal- lization of plagioclase decreases with increasing amounts of olivine, such that troctolitic gabbros relatively undeformed. Degree of dynamic recrystallization is positively correlated with modal abundance of orthopyroxene. Therefore, the more highly evolved rocks generally show higher degrees of plagioclase recrystallization. These patterns have important implications for the relative strength characteristics of newly generated oceanic crust, as discussed below.

\section{Variations in Predominant Neoblast Size}

The suite of variably recrystallized gabbroic rocks shows a lack of correlation of neoblast size with degree of dynamic recrystallization for almost the full range of plagioclase neoblast sizes $(100-500 \mu \mathrm{m})$ (Fig. 6). This suggests that the changes in physical conditions that produced the neoblast size variations were not sufficient to strongly affect spatial partitioning of strain at the thin-section scale.

The spectrum of predominant neoblast size for plagioclase is moderately skewed toward smaller grain sizes and contains a strong maximum between 101 and $300 \mu \mathrm{m}$ (Fig. 7A). Clinopyroxene shows an even greater skewing toward smaller grain sizes and contains a maximum between 0 and $100 \mu \mathrm{m}$ (Fig. 7C). In contrast, olivine shows no development of a preferential neoblast size over the range from 0 to $500 \mu \mathrm{m}$ (Fig. 7B). Within individual samples, the difference between the maximum and minimum neoblast size increases systematically with increases in predominant neoblast size (Fig. 8). In general, predominant neoblast size is closer to minimum neoblast size in rocks with smaller neoblasts $(10-200 \mu \mathrm{m})$ and closer to the 

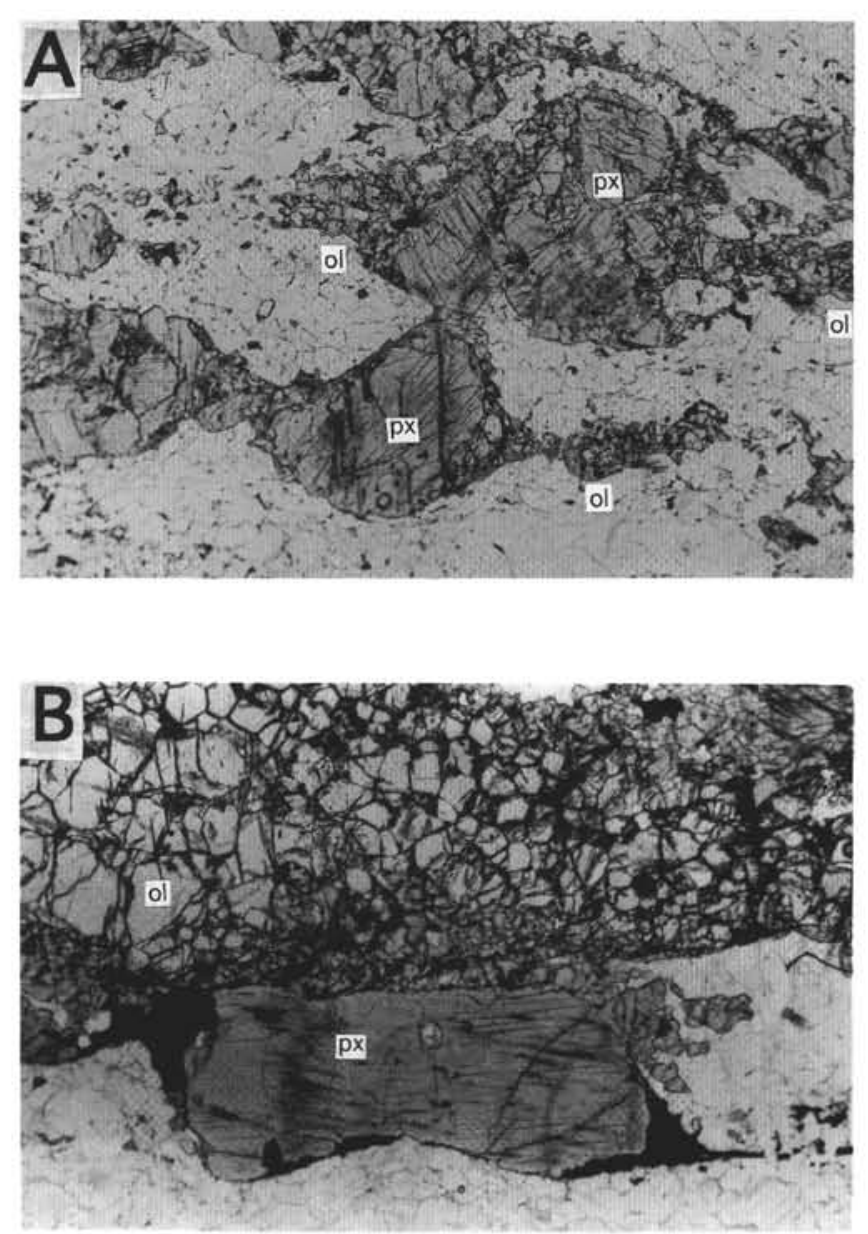

Figure 4. Contrasts in degree of dynamic recrystallization of olivine and clinopyroxene. A. Clinopyroxene porphyroclasts (px) with strain shadows of olivine (ol) (Sample 153-923A-13R-1, 135-144 cm). Plane-polarized light. Field length is $4 \mathrm{~mm}$. Uphole direction is $20^{\circ}$ counterclockwise from the short axis of the photograph. B. Clinopyroxene (px) is unrecrystallized and contains asymmetric strain shadows of iron oxide that indicate sinistral shear (Sample 153-923A-2R-2, 40-44 cm). Immediately above, an olivine host grain (ol) is thoroughly recrystallized except for a very small part of the core. Note the decrease in size of the olivine neoblasts with distance from the core. Plane-polarized light. Field length is $4 \mathrm{~mm}$. Uphole direction is $30^{\circ}$ clockwise from the short axis of the photograph.

maximum in rocks with larger neoblasts $(300-500 \mu \mathrm{m})$. The largest neoblasts observed are $800-1000 \mu \mathrm{m}$. These are typically polygonal and have well-defined grain boundaries (Fig. 9). In general, visual estimates of the strength of preferred lattice fabrics in plagioclase increases as predominant neoblast size decreases.

\section{Semibrittle Fabrics}

In some samples, brittle deformation in the form of microcracking and more distributed cataclasis commonly is also accompanied by varying degrees of dynamic recrystallization. Although this microstructural group only contains eight samples, it is important from a genetic point of view because it marks the transition between the two dominant deformation mechanisms that affect the gabbroic rocks. In general, brittle microstructures that formed during dynamic recrystallization are only found in rocks with smaller predominant neoblast sizes ( $120 \mu \mathrm{m}$ to submicroscopic). Samples with semibrittle microstructures typically are strongly dominated by either dynamic recrystallization or cataclasis, which we interpret to reflect important differences in physical conditions of deformation.
A

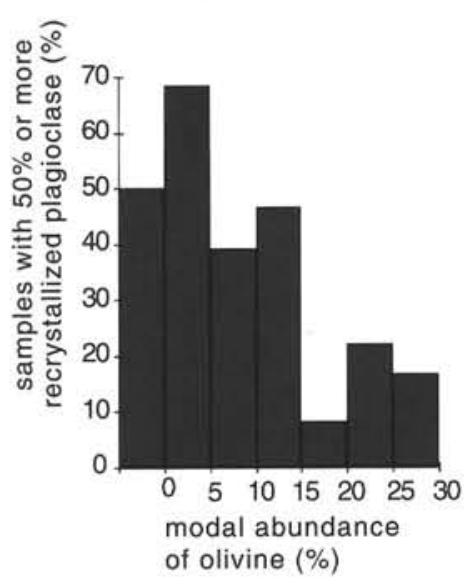

Figure 5. Host-rock composition and degree of dynamic recrystallization. The histograms show that degree of dynamic recrystallization (A) systematically decreases with modal abundance of olivine, and (B) systematically increases with modal abundance of orthopyroxene.

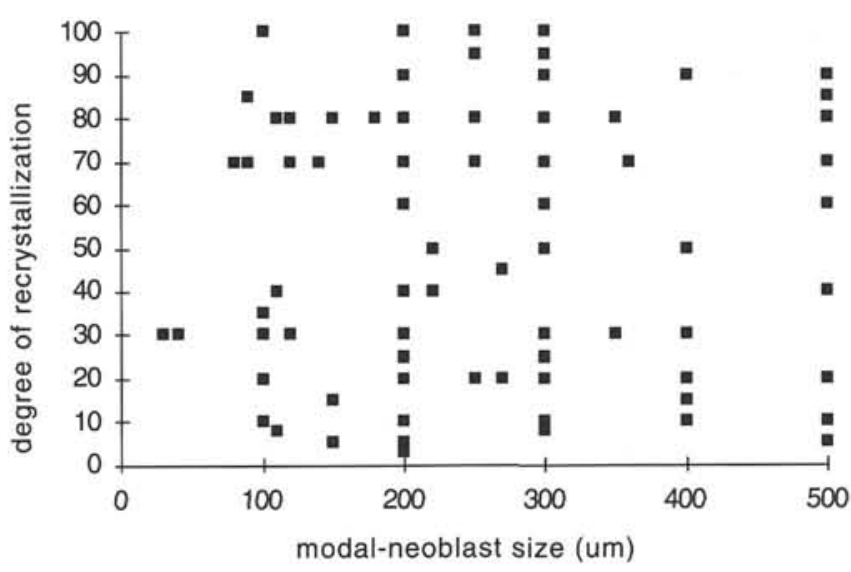

Figure 6. Degree of recrystallization plotted vs. the predominant neoblast size of plagioclase. Random distribution suggests that strain was not strongly partitioned in rocks containing predominant neoblast sizes between 100 and $500 \mu \mathrm{m}$. It is likely that the degree of recrystallization reflects differences in magnitude of accumulated strain.

Some coarse-grained and pegmatitic gabbros from Sites 921 and 923 contain semibrittle microstructures that are dominated by dynamic recrystallization. Microcracking and veins in primary pyroxene and feldspar are commonly filled with neoblastic feldspar (Fig. 10). Neoblasts are small $(30-120 \mu \mathrm{m})$ and have irregular to sutured grain boundaries. In addition to microcracking, primary feldspar grains have patchy to undulatory extinction, bent twins and deformation twins, and typically contain thin trails and irregular patches of neoblasts.

These coarse-grained and pegmatitic gabbros commonly show evidence for extensive alteration in the form of amphibolitization of pyroxene and albitization of feldspar (e.g., Sample 153-921E-8R-1, 91-95 cm). Neoblastic feldspar is andesine $\left(A_{35}-A_{45}\right)$, whereas the primary feldspar is labradorite $\left(\mathrm{An}_{50}-\mathrm{An}_{60}\right)$. Primary plagioclase grains display highly sutured fronts of albitization that occur both concentrically around their margins and internally along healed intragranular fractures. Amphibole is green and brown, and is typically found along the margins and cleavage planes of primary pyroxene grains. Amphiboles have hornblendic to pargasitic compositions, and are rich in aluminum, alkalies, and titanium. Other samples of the 
A

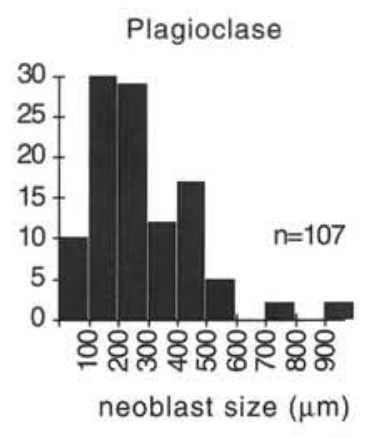

B

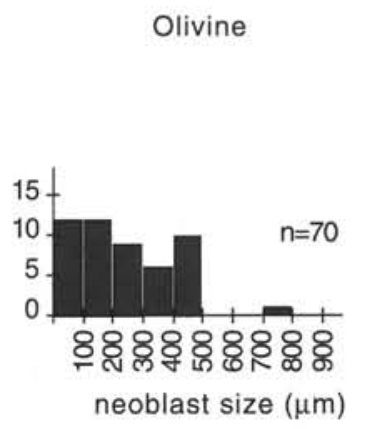

C

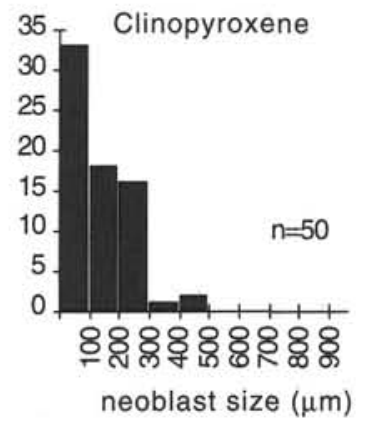

Figure 7. Histograms of predominant neoblast size $(\mu \mathrm{m})$ for (A) plagioclase, (B) olivine, and (C) clinopyroxene.

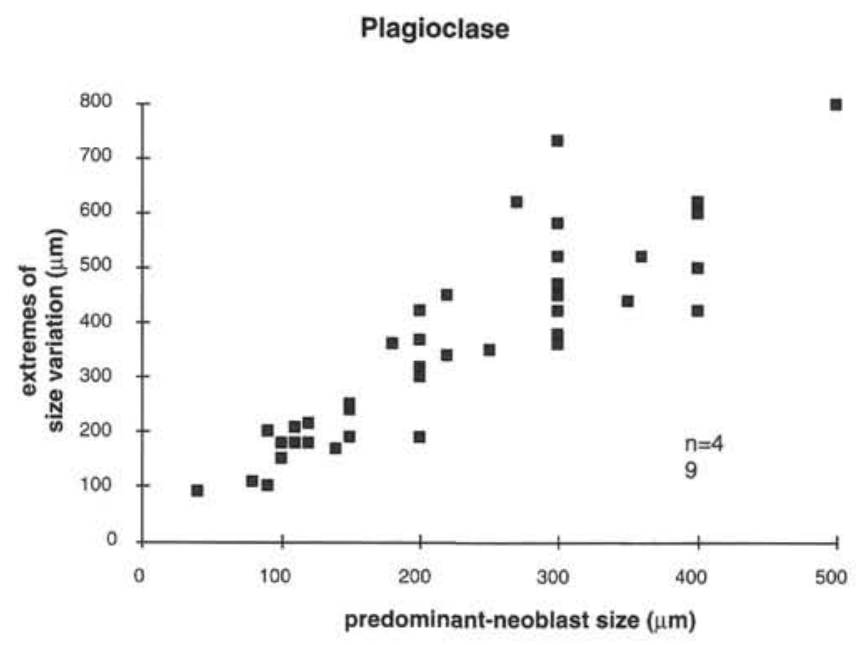

Figure 8. Plot of the dispersion of neoblast size vs. predominant neoblast size.

pegmatitic gabbro display this style of alteration without any significant neoblast development and with much lower degrees of brittle deformation (e.g., Sample 153-921E-8R-1, 80-85 cm). In these samples, irregular amphibole-bearing veins commonly appear to terminate at the margins of coherent feldspar grains. However, within the feldspar grains, the vein traces are defined by discrete inclusion trails and broader zones of albitization. It is possible that much of the more albitic feldspar is new material that grew in optical continuity with the primary grain as the vein opened.

A different style of semibrittle fabric is seen in samples dominated by cataclastic microstructures. The operation of both crystal-plastic and cataclastic deformation mechanisms in protocataclastic rocks is suggested by the intimate occurrence of neoblasts along microcracks. Commonly, patches of neoblasts are found along one wall of microcracks or veins. Although it is possible that the neoblasts are older and unrelated to the brittle deformation, in many cases, the distance to the next patch of neoblasts in the opposite wall greatly exceeds the amount of offset across the microcrack, as determined by the displacement of original grain boundaries. Less commonly, arrays of microcracks end in neoblast mosaics, which suggests that the microstrructures developed coevally (e.g., Sample 153-921B-1W-1, $64-67 \mathrm{~cm}$ ).

In cataclastic and ultracataclastic shear zones, feldspar porphyroclasts typically occur as subrounded equant clasts, augen, or highly elongated ribbons with aspect ratios as high as 15:1 (e.g., Sample 153-921B-1W-1, 26-32 cm) (Fig. 11). Equant grains and augen cores generally show undulose extinction and, less commonly, weak development of polygonal subgrains, whereas ribboned grains are composed of a fine-grained to submicroscopic $(<10 \mu \mathrm{m})$ aggregate of recrystallized grains. Contacts between the augen cores and recrystal-

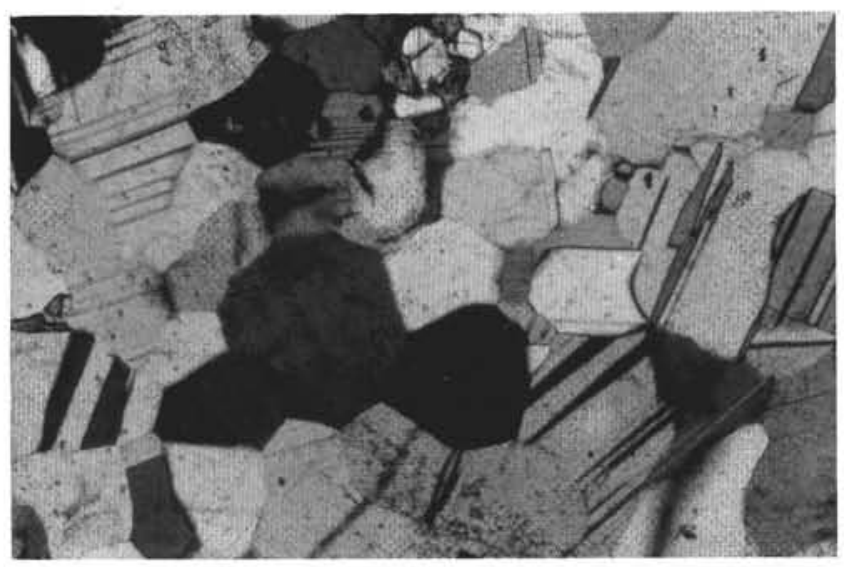

Figure 9. Largest observed neoblasts. The nearly extinct neoblast (left center) is about $800 \mu \mathrm{m}$ in diameter and is incipiently penetrated by a smaller neoblast along its lower left margin (Sample 153-923A-8R-3, 23-27 cm). Field length is $4 \mathrm{~mm}$. Uphole direction is parallel to the short axis of the photograph.

lized tails are finely sutured. Ribboned plagioclase grains, as well as material in augen tails, are typically albite $\left(\mathrm{An}_{10}-\mathrm{An}_{20}\right)$, whereas the equant grains are labradorite $\left(\mathrm{An}_{55}-\mathrm{An}_{60}\right)$. Generally, clasts that still retain their protolith compositions are as small as $20 \mu \mathrm{m}$ in diameter and can occur within $100 \mu \mathrm{m}$ of the elongated recrystallized grains (Table 1). Submicroscopic gouge also shows important changes in mineralogy in different domains in the cataclastic zones. Gouge located near equant plagioclase porphyroclasts typically yielded protolith-phase compositions of either plagioclase or clinopyroxene, which suggests that granulation occurred without recrystallization or alteration in these domains (e.g., Table 1). In contrast, gouge near ribboned grains commonly contained hydrous phases, such as chlorite and amphibole.

Although the ductile ribboned grains and augen tails appear ductile at the microscopic scale, the nearly submicroscopic recrystallized grain size makes it impossible to prove that the grains deformed crystal-plastically without transmission electron microscopy (e.g., Rutter, 1986). However, microstructurally, these grains are identical to experimentally deformed aggregates that were shown to have been produced by recrystallization-accommodated dislocation creep (Tullis and Yund, 1985). If true, the strong difference in grain shape and internal recrystallization with changes in composition suggests that the free energy of albitization was an important driving force for this style of dynamic recrystallization. Numerous studies have documented changes in feldspar composition with dynamic recrystallization (e.g., Vernon, 1975; White, 1975; Allison et al., 1979; Borges and White, 1980; Brown et al., 1980; Vidal et al., 1980; Hanmer, 1982; Watts and Williams, 1983; Olsen and Kohlstedt, 1985). However, net changes in An content as high as $30-50$ are rare. The presence of hy- 


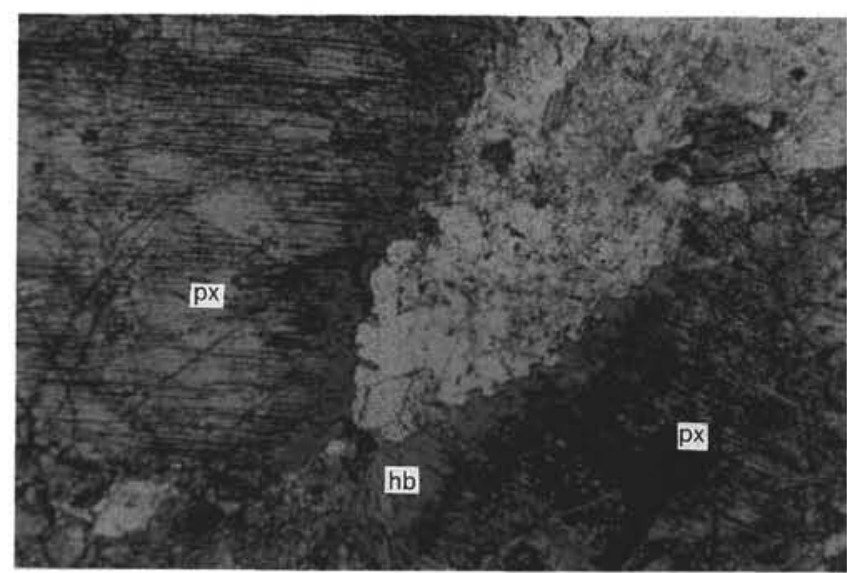

Figure 10. Recrystallization-dominated semibrittle microstructure of Sample 153-921E-8R-1, 91-95 cm (plane-polarized light). Microcrack in clinopyroxene $(\mathrm{px})$ is lined by green-brown amphibole $(\mathrm{hb})$ and filled with neoblastic feldspar. Crack shows differential tensile offset and angular differences between the crack walls. Cleavage traces and extinction positions of the clinopyroxene in the two walls are exactly the same $\left(22^{\circ}\right)$. Field length is $4 \mathrm{~mm}$. Uphole direction is parallel to the short axis of the photograph.

drous phases in gouge near ribboned grains suggests that these domains equilibrated with higher aqueous fluid pressures than the anhydrous domains. Therefore the mass transfer of albitization and the potential crystal plasticity in the ribboned grains would have been enhanced considerably by such elevated pore-fluid pressures (e.g., Tullis and Yund 1980; Bell and Johnson, 1989).

\section{Brittle Fabrics}

The dominant brittle microfabrics include cataclastic shear zones discrete shear fractures, and veins that record tensile offset. The intensity of cataclasis is highly variable and samples show full gradation from (1) protocataclastic fabrics, in which original grain boundaries are discernible despite high fracture densities, (2) cataclastic fabrics, in which original grain boundaries are largely destroyed, but the fabric remains clast supported, and (3) ultracataclastic fabrics, which commonly contain $15-100 \mu \mathrm{m}$ clasts floating in submicroscopic gouge. Often, this full transition occurs across the width of a single shear zone. Shear zones commonly show asymmetrical fabric development; one margin shows a gradational transition to ultracataclastic fabric and the other shows a sharp planar contact between ultracataclasis and protocataclasis.

\section{KINEMATICS}

Most of the major types of microfabrics contain striae or stretching lineations that are consistently oriented within $20^{\circ}$ of the maximum dip direction of the foliation, assuming that the core is vertical. The crystal-plastic fabrics are strongly lineated L- and LS-tectonites. In some samples (e.g., Sample 153-923A-2R-2, 96-102 cm), the aspect ratios of recrystallized clinopyroxene grains are indistinguishable in thin sections cut subparallel to the $\mathrm{XY}$ and $\mathrm{XZ}$ planes of finite strain. However in other samples (e.g., Sample 153-923A-13R-1, $135-144 \mathrm{~cm}$ ), aspect ratios of recrystallized clinopyroxene grains are similar in thin sections cut subparallel to $\mathrm{XY}$ and $\mathrm{YZ}$ planes of finite strain. These relationships suggest that the crystal-plastic fabrics record constrictional to plane strain.

Shear-sense indicators are abundant in most of the major types of microfabrics and consistently display a normal sense of shear. In microcataclastic zones, drag structures along the margins are the most common and form reliable shear-sense indicators. However, less

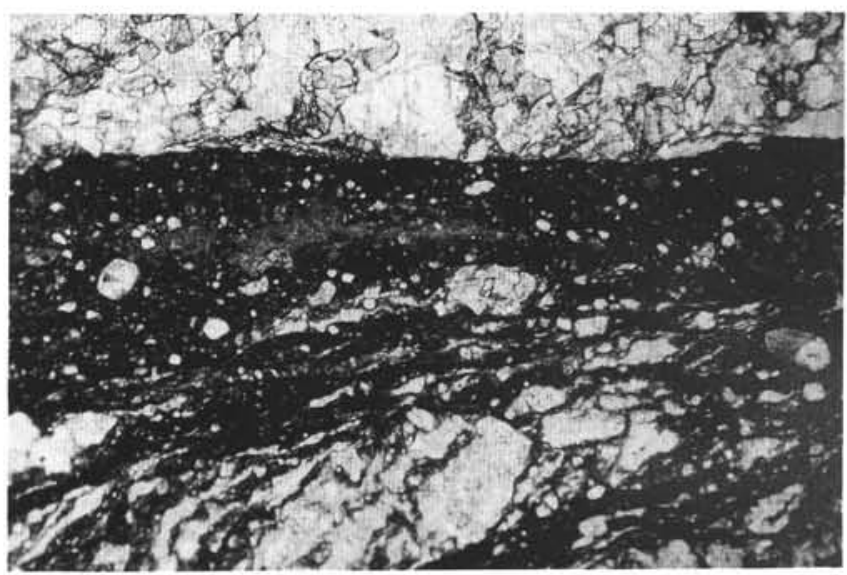

Figure 11. Cataclastic-dominated semibrittle shear zone in Sample 153921B-1W-1, 26-32 cm (plane-polarized light). Cataclastic zone is composed of dark submicroscopic gouge and small, round, clasts of relict feldspar and clinopyroxene. Upper boundary is sharp and straight. Lower boundary is diffuse and is composed of elongated ribbons of albitized feldspar. Drag of albitic ribbons in the cataclastic zone indicates dextral shear. Field length is 4 $\mathrm{mm}$. Uphole direction is $20^{\circ}$ counterclockwise from the short axis of the photograph.

commonly, the orientations of microreidel shears and conjugate sets of tensile cracks also indicate stress configurations that are consistent with normal-sense offset across cataclastic zones. Drag structures are also common along the margins of semibrittle and crystal-plastic shear zones (Figs. 11, 12). Semibrittle and crystal-plastic microfabrics also display delta- and sigma-type porphyroclasts (the latter of which can be seen in Figs. 4A and 4B), asymmetric oxide pressure shadows around pyroxene porphyroclasts (Fig. 5B). Oddly, SC foliations and $C^{\prime}$ shear bands are not common in the crystal-plastic shear zones.

In general, the degree of porphyroclast asymmetry decreases as predominant neoblast size increases. In fact, nearly symmetric porphyroclasts dominate crystal-plastic microfabrics with predominant neoblast sizes greater than $250 \mu \mathrm{m}$. Therefore, characterization of kinematics in these rocks is nearly impossible by simple petrographic inspection.

\section{OVERPRINTING RELATIONSHIPS}

Crosscutting relationships of microfabrics and compositional zoning of minerals demonstrate that the suite of gabbroic rocks records progressive unroofing. Brittle deformational fabrics always overprint crystal-plastic and magmatic fabrics except, of course, in the special cases of semibrittle microfabrics. Likewise, the wall rocks of discrete crystal-plastic shear zones always contains either magmatic fabrics or crystal-plastic fabrics with a larger neoblast size. In contrast, larger neoblasts are never observed penetrating and overprinting significantly smaller neoblasts. The strong skewing of the histogram of predominant neoblast sizes toward the smaller size range (Fig. 7) is consistent with the systematic decrease in neoblast size. The significance of these observations are discussed below.

\section{DISCUSSION}

Gabbroic rocks sampled during Leg 153 record four main categories of microstructures and deformation mechanisms: magmatic fabrics, solid-state plastic fabrics, semibrittle fabrics, and brittle fabrics. This study demonstrates that transitions between the main categories are gradational and suggests that, at the scale of the drill cores, micro- 
Table 1. Feldspar compositions from cataclastic-dominated semibrittle shear zones.

\begin{tabular}{|c|c|c|c|c|c|c|c|c|c|c|c|c|c|c|c|}
\hline $\begin{array}{l}\text { Core, section, } \\
\text { interval }(\mathrm{cm})\end{array}$ & Occurrence & An & $\mathrm{Na}$ & $\mathrm{Ca}$ & $\mathrm{Mg}$ & $\mathrm{Fe}$ & $\mathrm{Si}$ & $\mathrm{Al}$ & $\mathrm{Ti}$ & K & $\mathrm{F}$ & $\mathrm{Cl}$ & Mn & $\mathrm{O}$ & Total \\
\hline \multicolumn{16}{|l|}{153} \\
\hline $921 \mathrm{~B}-1 \mathrm{~W}-1,26-32$ & Relict grain & 58 & 3.44 & 8.29 & 0.00 & 0.07 & 24.85 & 15.05 & 0.03 & 0.04 & 0.11 & 0.00 & 0.00 & 46.33 & 98.21 \\
\hline 92 ID-5R-1, 44-48 & Relict grain & 58 & 3.57 & 8.59 & 0.01 & 0.20 & 25.03 & 14.39 & 0.07 & 0.05 & 0.05 & 0.00 & 0.00 & 46.18 & 98.13 \\
\hline $921 \mathrm{~B}-1 \mathrm{~W}-1,26-32$ & Gouge & 58 & 3.53 & 8.53 & 0.36 & 0.40 & 25.02 & 14.29 & 0.01 & 0.03 & 0.01 & 0.01 & 0.02 & 46.30 & 98.50 \\
\hline $921 \mathrm{~B}-1 \mathrm{~W}-1,26-32$ & Clast $(20 \mu \mathrm{m})$ & 57 & 3.51 & 8.09 & 0.00 & 0.16 & 25.13 & 14.99 & 0.03 & 0.03 & 0.11 & 0.01 & 0.00 & 46.55 & 98.59 \\
\hline $921 \mathrm{~B}-1 \mathrm{~W}-1,26-32$ & Clast $(40 \mu \mathrm{m})$ & 57 & 3.52 & 8.01 & 0.02 & 0.17 & 25.07 & 14.90 & 0.05 & 0.04 & 0.00 & 0.00 & 0.02 & 46.43 & 98.23 \\
\hline $921 \mathrm{~B}-1 \mathrm{~W}-1,26-32$ & Clast $(50 \mu \mathrm{m})$ & 56 & 3.63 & 8.20 & 0.00 & 0.17 & 25.03 & 14.69 & 0.04 & 0.04 & 0.00 & 0.00 & 0.01 & 46.28 & 98.08 \\
\hline $921 \mathrm{D}-5 \mathrm{R}-1,44-48$ & Clast $(8 \mu \mathrm{m})$ & 42 & 4.46 & 5.74 & 0.05 & 0.20 & 27.59 & 13.16 & 0.04 & 0.04 & 0.00 & 0.01 & 0.00 & 47.19 & 98.48 \\
\hline $921 \mathrm{~B}-1 \mathrm{~W}-1,26-32$ & Ribbon & 29 & 5.95 & 4.17 & 0.96 & 0.47 & 29.22 & 11.62 & 0.00 & 0.02 & 0.03 & 0.03 & 0.04 & 48.23 & 100.72 \\
\hline $921 \mathrm{D}-5 \mathrm{R}-1,44-48$ & Ribbon & 17 & 7.18 & 2.58 & 0.01 & 0.05 & 30.32 & 11.31 & 0.00 & 0.03 & 0.00 & 0.02 & 0.05 & 48.26 & 99.80 \\
\hline $921 \mathrm{~B}-1 \mathrm{~W}-1,26-32$ & Ribbon & 14 & 7.29 & 2.12 & 0.00 & 0.06 & 30.96 & 11.50 & 0.00 & 0.03 & 0.00 & 0.02 & 0.00 & 49.00 & 100.98 \\
\hline
\end{tabular}

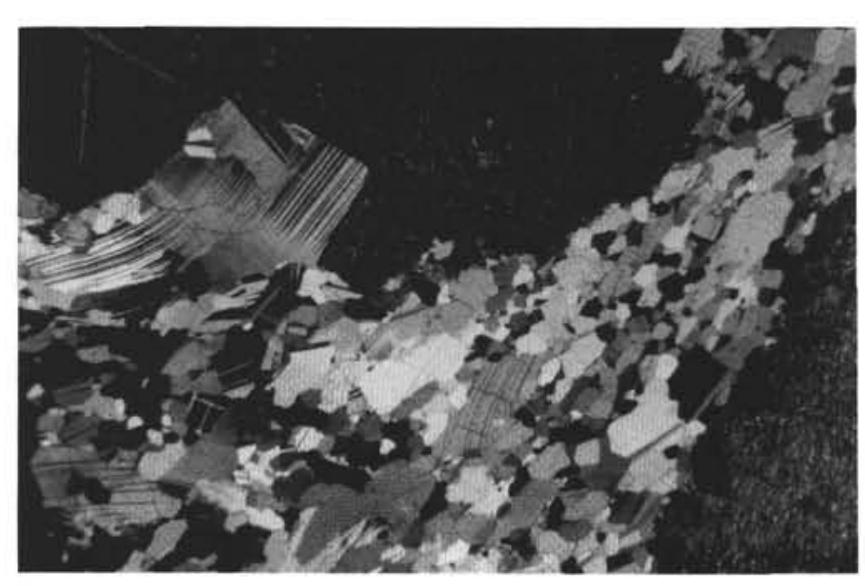

Figure 12. Crystal-plastic deformation of primary subophitic texture in Sample 153-923A-3R-2, 14-20 cm (cross-polarized light). Partially included euhedral plagioclase is bent and recrystallized in shear zone along the margin of unrecrystallized clinopyroxene grain. Sense of drag of euhedral plagioclase indicates dextral shear. Field length is $1.33 \mathrm{~cm}$. Uphole direction is $45^{\circ}$ counterclockwise from the short axis of the photograph.

fabrics formed in response to continuous variations in physical conditions (e.g., temperature, stress, and pore-fluid pressure) through time.

If diffusion creep is an important deformation mechanism associated with dynamic recrystallization, numerous theoretical, experimental, and empirical studies have shown that neoblast size is a function of paleostress (e.g., Takeuchi and Argon, 1976; Nicolas and Poirier, 1976; Twiss, 1977; White, 1979; Karato et al., 1980; Karato, 1984; Poirier, 1985; Van der Wal et al., 1993). According to flow laws for diffusion creep, paleostress is in turn a function of temperature, hydrolytic weakening, and strain rate. Therefore, decreases in neoblast size could be the result of decreases in temperature, decreases in hydrolytic weakening, or increases in strain rate. We interpret the systematic decrease in neoblast size to most strongly reflect a decrease in temperature because (1) Fletcher, Stephens, et al. (this volume) show that water:rock interactions progressively increased, and (2) it is unlikely that strain rates only increased in the deformation zone. A decrease in temperature is also consistent with the transition from crystal-plastic to cataclastic deformation mechanisms, compositional zoning and evolution of amphibole compositions (Fletcher, Stephens, et al., this volume), and the progressive unroofing that is required to emplace these lower crustal rocks on the seafloor.

One of the most intriguing results of this study is the strong systematic increase in the degree of plagioclase recrystallization in the more evolved gabbroic rocks. Deformation experiments show that under similar experimental conditions, differences in steady-state flow laws between albite and anorthite are relatively minor compared to the differences that exist between any other reported mineral pairs (Kirby and Kronenberg, 1987). This suggests that the much smaller observed variation in feldspar composition (labradorite to andesine) is not likely to account for the difference in degree of recrystallization. Therefore, the observed partitioning must reflect some other control of rock strength. For example, if the volatile content of magma was elevated by fractional crystallization, fluid pressures would be consistently higher in the evolved rocks and hydrolytic weakening could explain the difference in degree of recrystallization. Of course, this would require deformation to occur soon after or during crystallization of the evolved magma, which is consistent with detailed relationships documented by Cannat, Ceuleneer, et al. (this volume). In contrast, it is difficult to envision some process that would consistently elevate the temperature of the more evolved rocks, especially given the close and cyclical distribution of evolved and more primitive gabbros in the cores (Shipboard Scientific Party, 1995b).

\section{CONCLUSIONS}

1. Gabbroic rocks from Leg 153 contain a full spectrum of microfabrics that developed in conditions that ranged from magmatic state to very low-grade solid state. Crosscutting relationships show that neoblast size progressively diminished and that deformational style evolved from ductile to brittle.

2. The most common deformational fabric developed in these rocks is a crystal-plastic fabric that accommodates a normal sense of shear. Plagioclase neoblasts are dominantly 100-200 $\mu \mathrm{m}$, clinopyroxene neoblasts are dominantly $<100 \mu \mathrm{m}$, and olivine neoblasts show no dominant size.

3. Of the three main mineral phases that make up the gabbroic rocks, clinopyroxene, olivine, and plagioclase typically show the lowest, intermediate, and highest degrees of recrystallization, respectively. Microstructural evidence shows that variations in degree of recrystallization in these three minerals reflect relative differences in strain magnitude.

4. Crystal-plastic strain is strongly partitioned into more highly evolved rock types, such as gabbro norite and ferrogabbro. Degree of dynamic recrystallization of plagioclase increases systematically with increases in the abundance of orthopyroxene and with decreases in the abundance of olivine.

\section{ACKNOWLEDGMENTS}

The first author wishes to thank John Bartley for an illuminating discussion that significantly improved the manuscript. Carol Simpson, Andreas Kronenberg, and Jeff Karson provided detailed reviews that elevated the quality of this study considerably. Guillermo Rubio and Gabriel Rendon provided many hours of creative technical support to process samples used in this study. 


\section{REFERENCES}

Agar, S.M., 1994. Rheological evolution of the oceanic crust-a microstructural view. J. Geophys. Res., 99:3175-3200.

Allison, I., Barnet, R.L., and Kerrich, R., 1979. Superplastic flow and changes in crystal chemistry of feldspars. Tectonophysics, 53:41-46.

Bell, T.H., and Johnson, S.E., 1989. The role of deformation partitioning in the deformation and recrystallization of plagioclase and K-feldspar in the Woodroffe Thrust mylonite zone, central Australia. J. Metamorph. Geol., 7:151-168

Borges, F.S., and White, S.H., 1980. Microstructural and chemical studies of sheared anorthosites, South Harris. J. Struct. Geol., 2:273-280.

Brown, W.L., Macaudiere, J., Ohnenstetter, D., and Ohnenstetter, M., 1980 Ductile shear zones in a meta-anorthosite from Harris, Scotland: textural and compositional changes in plagioclase. J. Struct. Geol., 2:281-287.

Hanmer, S.K., 1982. Microstructure and geochemistry of plagioclase and microcline in naturally deformed granite. J. Struct. Geol., 4:197-213.

Hobbs, B.E., Means, W.D., and Williams, P.F., 1976. An Outline of Structural Geology: New York (Wiley).

Karato, S., Toriumi, M., and Fuji, T., 1980. Dynamic recrystallization of olivine single crystals during high-temperature creep. Geophys. Res. Lett., 7:649-652

Karato, S.I., 1984. Grain-size distribution and rheology of the upper mantle. Tectonophysics, 104:155-176.

Karson, J.A., 1990. Seafloor spreading on the Mid-Atlantic Ridge: implications for the structure of ophiolites and oceanic lithosphere produced in slow-spreading environments. In Malpas, J., Moores, E.M., Panayiotou, A., and Xenophontos, C. (Eds.), Ophiolites: Oceanic Crustal Analogues: Proc. Symp. "Troodos 1987": Nicosia, Cyprus (Minist. Agric. Nat. Resour.), 547-555.

Kirby, S.H., and Kronenberg, A.K., 1987. Rheology of the lithosphere: selected topics. J. Geophys. Res., 25:1219-1244.

Nicolas, A., and Poirier, J.-P., 1976. Crystalline Plasticity and Solid State Flow in Metamorphic Rocks: New York (Wiley).

Olsen, T.S., and Kohlstedt, D.L., 1985. Natural deformation and recrystallization of some intermediate plagioclase feldspars. Tectonophysics, 111:107-131

Patterson, S.R., Vernon, R.H., and Tobisch, O.T., 1989. A review of the criteria for identification of magmatic and tectonic foliations in granitoids. J. Struct. Geol., 11:349-363.

Philpotts, A.R., 1990. Principles of Igneous and Metamorphic Petrology: Englewood Cliffs, NJ (Prentice Hall).

Poirier, J.P., 1985. Creep of Crystals: High Temperature Deformation Processes in Metals, Ceramics, and Minerals: Cambridge (Cambridge Univ. Press).

Rutter, E.H., 1986. On the nomenclature of mode of failure transitions in rocks. Tectonophysics, 122:381-387.

Shipboard Scientific Party, 1995a. Explanatory notes. In Cannat, M., Karson, J.A., Miller, D.J., et al., Proc. ODP, Init. Repts., 153: College Station, TX (Ocean Drilling Program), 15-42.

, 1995b. Site 923. In Cannat, M., Karson, J.A., Miller, D.J., et al. Proc. ODP, Init. Repts., 153: College Station, TX (Ocean Drilling Program), 217-258.

Takeuchi, S., and Argon, A.S., 1976. Steady-state creep of single-phase crystalline matter at high temperature. J. Mater. Sci., 11:1542-1566.

Tullis, J., and Yund, R.A., 1980. Hydrolytic weakening of experimentally deformed Westerly Granite and Hale albite rock. J. Struct. Geol., 2:439451 .

, 1985. Dynamic recrystallization of feldspar, a mechanism for ductile shear zone formation. Geology, 13:238-241.

Twiss, R.J., 1977. Theory and applicability of a recrystallized grain-size paleopiezometer. Pure Appl. Geophys., 115:227-244.

Van der Wal, D., Prame, C., Drury, M., and FitzGerald, J., 1993. Relationships between dynamically recrystallized grain size and deformation conditions in experimentally deformed olivine rocks. Geophys. Res. Lett. 20:1479-1482.

Vernon, R.H., 1975. Deformation and recrystallization of a plagioclase grain. Am. Mineral., 60:884-888.
Vidal, J.C., Kubin, L., Dobat, P., and Soula, J.C., 1980. Deformation and dynamic recrystallization of $\mathrm{K}$-feldspar augen in orthogneiss from Montagne Noire, Occitania, southern France. Lithos, 13:247-255.

Watts, M.J. and Williams, G.D., 1983. Strain geometry, microstructure and mineral chemistry in metagabbro shear zones: a study of softening mechanisms during progressive mylonitization. J. Struct. Geol., 5:507-517.

White, J.C., 1975. Tectonic deformation and recrystallization of oligoclase. Contrib. Mineral. Petrol., 50:287-305.

White, S., 1979. Grain and subgrain size variations across a mylonite zone. Contrib. Mineral. Petrol., 70:193-202.

\section{Date of initial receipt: 3 August 1995 \\ Date of acceptance: 4 March 1996 \\ Ms 153SR-010}

\section{APPENDIX}

\section{Domainal Variations}

Classification of microfabrics into groups helps define important structural domains and downhole variations in structural style (Fig. 13). Major categories in the new classification scheme are based on (1) dominant deformation mechanism, (2) degree of dynamic recrystallization, and (3) predominant neoblast size. Like the shipboard classification scheme, this one is based mainly on microstructural characteristics of plagioclase, which makes up $50 \%-70 \%$ of the gabbroic rocks. The classification system reflects the main strength of the database and emphasizes individual components of the microfabrics. Distinctions between degrees of dynamic recrystallization can be separated from predominant grain size. Main categories of microfabrics include the following:

PM: primary magmatic texture. These samples contain less than $20 \%$ neoblasts and no brittle microstructures. A single modifier denotes the degree of preferred alignment of plagioclase laths ( $\mathrm{r}=$ random, $\mathrm{a}=$ aligned).

RX: dynamically recrystallized fabrics. First numeric modifier signifies the degree of dynamic recrystallization $(1=20 \%-60 \%$, and $2=61 \%-100 \%$ ) and the second modifier signifies the predominant neoblast size $(\mathrm{a}=0-100$ $\mu \mathrm{m}, \mathrm{b}=101-300 \mu \mathrm{m}, \mathrm{c}=301-500 \mu \mathrm{m})$.

SB: semibrittle fabrics. This category includes samples containing microstructures indicative of both brittle and ductile deformation mechanisms. Microstructures show kinetic evidence and crosscutting relationships that suggest cataclastic deformation was coeval with dynamic recrystallization at the scale of the thin section.

CC: cataclastic fabrics. These samples display shear fractures and microbrecciation without any evidence of coeval dynamic recrystallization.

VN: These samples contain veins as the only brittle deformational fabric.

Some samples contain fabrics from two different groups, which is either a result of domainal variations or temporal overprinting. In cases of overprinting fabrics, they are listed in the order that they were acquired by the rock and separated by a forward slash (/). In cases of domainal variations, both fabric categories are listed and are separated by a semicolon (;).

In general, the spatial distribution of high-intensity crystal-plastic fabrics reflects the spatial distribution of the more evolved orthopyroxene-bearing gabbros (Fig. 13). Holes 921B, 921C, and 923A contain thick (1.5-20 m) sections of strongly developed crystal-plastic fabrics. Crystal-plastic fabrics are much more heterogeneously developed in potions of the core dominated by troctolite and olivine gabbro, which are most common in Holes 922A and $922 \mathrm{~B}$ and in the middle and lower parts of Hole $923 \mathrm{~A}$. Strong crystal-plastic fabrics within these sections typically occur in thin zones of more leucocratic material. Recrystallization-dominated semibrittle fabrics occur primarily in the very coarse-grained to pegmatitic gabbro unit of Hole 921E. Cataclastic fabrics are common in the upper portions of most holes, but also occur in lower portions of Hole 921E. Discrete veins are ubiquitous throughout the core, but an intense vein fabric is very well developed in Section 922A-2R-2. 
A

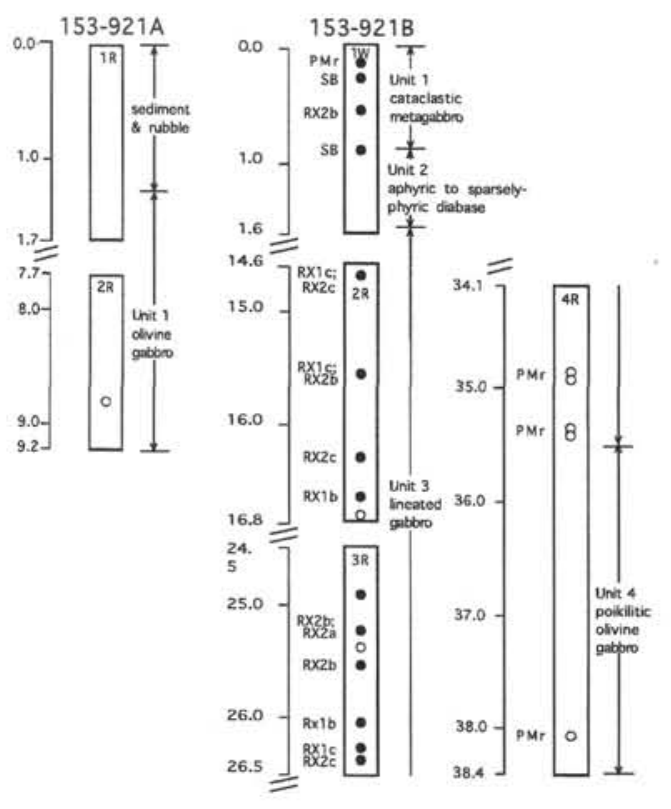

Site 921
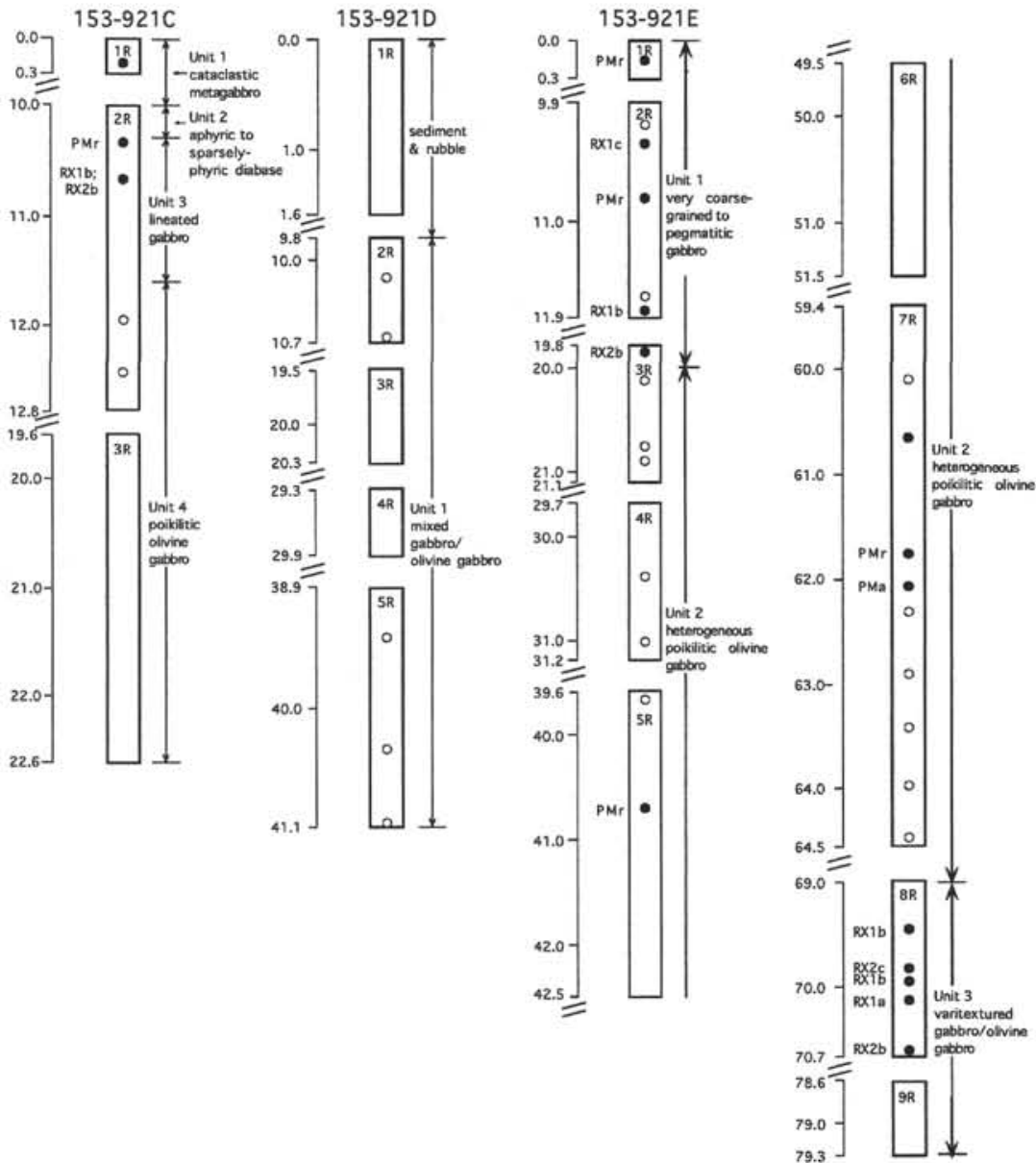

Figure 13. Plot of microstructural group and rock type through cores from (A) Site 921, (B) Site 922, and (C) Site 923. 
B

Site 922

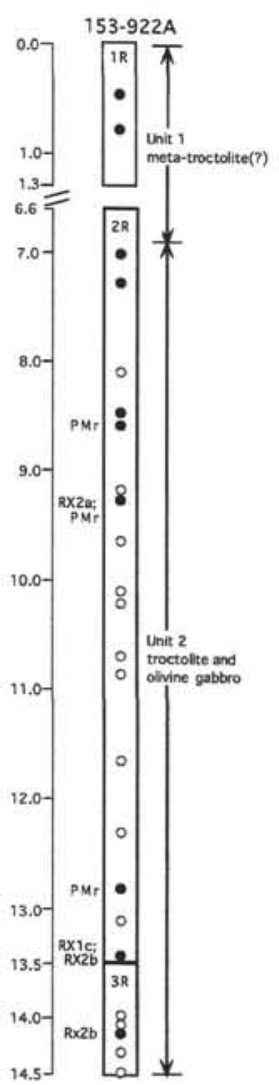

C ${ }^{153-923 A}$
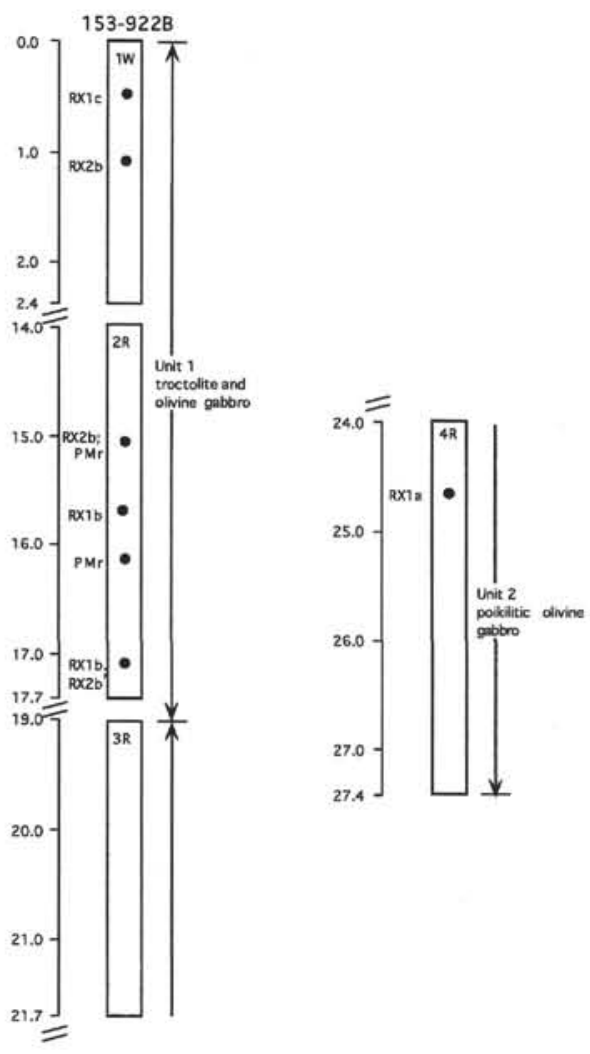
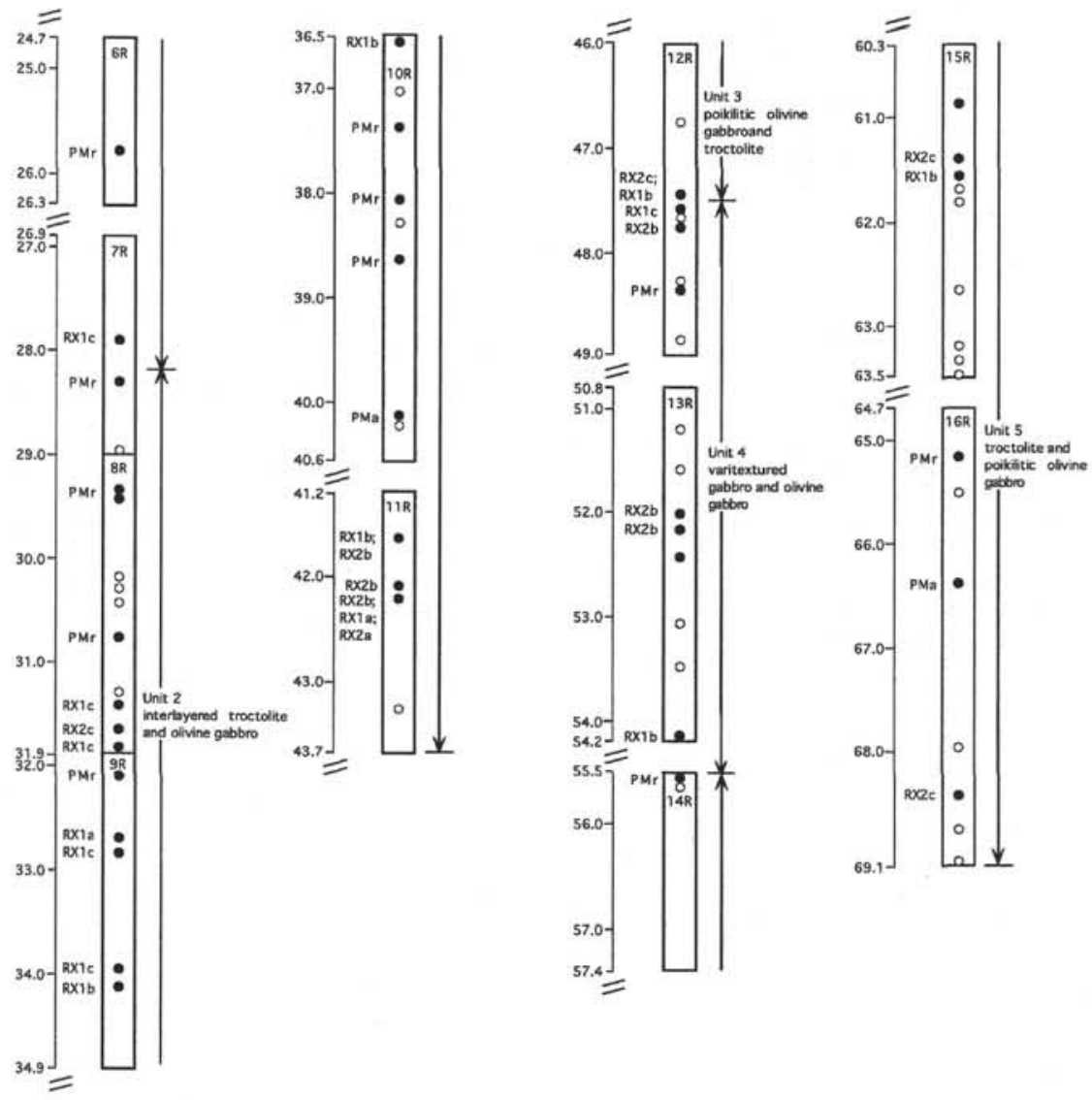

Figure 13 (continued). 